\title{
Do Perceived Pressure and Perceived Opportunity Influence Employees' Intention to Commit Fraud?
}

\author{
Tuan Zainun Tuan Mat ${ }^{1}$, Danny Shahmizi Teh Ismawi ${ }^{2}$ \& Erlane K Ghani ${ }^{3}$ \\ ${ }^{1}$ Faculty of Accountancy, Universiti Teknologi MARA, Malaysia \\ ${ }^{2}$ AML/CFT \& Financial Crime Unit, Maybank, Malaysia \\ ${ }^{3}$ Accounting Research Institute, Universiti Teknologi MARA, Malaysia \\ Correspondence: Erlane K Ghani, Accounting Research Institute, Universiti Teknologi MARA, Malaysia.
}

Received: April 20, 2019

Accepted: May 7, 2019

Online Published: May 19, 2019

doi:10.5430/ijfr.v10n3p132

URL: https://doi.org/10.5430/ijfr.v10n3p132

\begin{abstract}
Fraud has always remains an issue for organisations throughout the globe due to the increasing number of fraud occurrences over the years which resulted to the increasing amount of losses. Despite the large amount of efforts by organisations through internal control implementation and the amount of money spent to combat fraud, the numbers of fraud occurrences are still increasing. This study examines the employees' intention to commit fraud. Specifically, this study examines the influence of perceived pressure and perceived opportunity on employees' intention to commit fraud. In addition, this study examines the effect of capability in moderating the influence of perceived pressure and perceived opportunity on employees' intention to commit fraud. Using online questionnaire on 158 employees from various sectors, this study shows that the employees have a low intention to commit fraud. This study also shows an existence of linear relationship between perceived pressure and perceived opportunity on employees' intention to commit fraud. Consistent with previous studies, this study found that capability of the employees does not influence them to commit fraud. The findings in this study assist the employers to adopt appropriate strategies in preventing and detecting fraud possibility among their employees.
\end{abstract}

Keywords: fraud, fraud occurrences, intention, perception, perceived pressure, perceived opportunity, employees, intention, fraud prevention, Malaysia

\section{Introduction}

Fraud has always remains an issue for organisations throughout the globe due to the increasing number of fraud occurrences over the years which resulted to the increasing amount of losses. Despite the huge efforts by organisations through internal control implementation and the amount of money spent to combat fraud, the numbers of fraud occurrences are still increasing. CIFAS (2007) indicated that staff fraud has been a growing problem in the recent years in respect of investigations, confirmed cases, referrals and also unconfirmed cases. This trend affects business reputation, brand as well as employees' morality besides losing thousands of money (CIFAS, 2007).

Based on the survey conducted by KPMG Malaysia in 2013, 52\% of the respondents stated that fraud is a major problem in their organisation, while $83 \%$ felt that fraud is a major problem for Malaysian businesses in general. Out of the 52\% that have responded that fraud is a major problem for their organisation, $90 \%$ of the respondents felt that fraud is an inevitable cost in business. Eighty nine per cent of the respondents felt that the quantum of fraud has increased over the years with $94 \%$ respondents felt that the modus operandi of committing fraud has become more sophisticated and $85 \%$ respondents opined that fraud occurrences are increasingly aligned with the number and size of industry. In addition, a report in the Malaysian Insider (2013) has indicated that the number of fraud occurrences among bank employees has become alarming since the number of losses has increased to RM473.82 million within five years. He reported that $60 \%$ of the fraud was committed by employees, $30 \%$ of the fraud was committed by top management and the remaining $10 \%$ fraud was committed by the accountholders. It is therefore imperative for organisations to identify the reasons for employees to commit fraud.

Few studies have suggested on the importance of understanding fraud. For example: Voon et al. (2008) opined that understanding fraud and the reasons for committing fraud is important to combat fraud. Wells (2001) indicated that it is important for the Certified Public Accountants (CPA) to understand why a person commits fraud so they (the 
CPAs) can better assess the related risks and later implement appropriate preventive and detective measures. Other studies have provided similar opinions such as Rowlingson et al. (1997). Rowlingson et al. stated the importance of knowing why a person commits fraud in order to combat fraud. Sainsbury (2003) opined the same when he stated that there is lack of research on what motivates a person to commit fraud. Given the issues, concerns and implications discussed above, it is imperative to this the factors influencing employees to commit fraud in Malaysia.

This study examines employees' intention to commit fraud. Specifically, this study examines the influence of perceived pressure and perceived opportunity on employees' intention to commit fraud. This study also examines the effect of capability in moderating the influence of perceived pressure and perceived opportunity on employees' intention to commit fraud. The findings in this study could assist the employers in implementing appropriate preventive and detective measures. The remainder of this paper is structured as follows. The next section, Section 2 provides the literature review. Section 3 provides the research framework and hypotheses of this study. This is followed by Section 4 that outlines the research design. The results of the data analyses and discussions are shown in Section 5. The last section concludes this study.

\section{Literature Review}

Fraud refers to as a person using deception to conduct dishonest act for personal gain for one party and/or causes a loss to the other party (CIMA, 2009). Fraud is also defined as an illegal act or series of illegal acts committed by nonphysical means and by concealment or guile to obtain money or property, to avoid payment or loss of money or property, or to obtain business or personal advantage (Edelhertz, 1970; Bahrin, et.al 2018). Although the extent of fraud being undetected and unreported remains a mystery, it is clear that fraud activities impose an impact on economic cost, be it on the organisation and/ or the society as a whole (Free, 2015). Shanmugam et al. (2012) stated that to constitute an action as fraud, the misrepresentation or omission must have done knowingly and intentionally. Fraud must not be a result of a mistake nor an accident, or in negligence disregard of its truth or falsity.

The Association of Certified Fraud Examiners (ACFE) in 2010 has also indicated that perpetrators are usually first-time offenders of fraud. These offenders have never been charged before or convicted for fraud-related offense. Only $7 \%$ fraudsters have prior history of being charged in fraud-related offence. There are two types of fraud classified under perpetrators' intention to commit fraud. One is committed against the organisation and secondly, the fraud is committed on behalf of the organisation (Albrecht et al., 2012). Among these two types of fraud, employees committing fraud against the organisation is more common although more difficult to detect compared to fraud committed on behalf of the organisation (Herbert, 2005; and Boehm, 2007). This type of fraud is known as occupational fraud. Although the number of fraud occurrences is smaller for fraud committed on behalf of the organisation, the mean losses for this type of fraud are often larger than the fraud committed by employees against the organisation (KPMG, 2004)

Fraud committed by employees against the organisation can takes place in many ways. The ACFE Report to the Nations on Occupational Fraud and Abuses (2014) classified three categories of occupational fraud as follows:

(a) Asset misappropriation - involves theft or misuse of an organisation's assets.

(b) Corruption - the perpetrators wrongfully use their influence in a business transaction in order to procure some benefit for themselves, or another person, which is contrary to their duty to their employer or the rights of another person;

(c) Financial statement fraud - where it generally involves falsification of an organisation's financial statement.

The Fraud Triangle model introduced by Cressey (1953) indicated three elements of fraud. The elements are perceived pressure, perceived opportunity and rationalization. Cressey (1953) posited that a person who has non-shareable financial problem such as pressure uses an opportunity that he knows has a low risk of being detected (opportunity) and later justifies or rationalizes his behaviour (rationalization). The Fraud Triangle model is relevant in discussing employees committing fraud because this model has been widely accepted as the general cognitive idea to describe the situation (Murphy and Dacin, 2011; Mohamad, 2013; Bazmi \& Javed (2018). This study focuses on pressure and opportunity.

\subsection{Perceived Pressure}

The non-shareable (Note 1) financial problem is often refers to as pressure. Cressey (1953) in his study has categorised the real or perceived pressure into six basic categories. Real financial pressures includes but non exhaustive, includes falling behind on bills, unexpected medical expenses or a large amount of debt. Perceived financial pressure on the other hand, includes the desire to live a lifestyle that is beyond one's means or the desire to 
improve one's status (Fisher, 2015; Bosupeng, 2018)

A body of literature has examined the link between perceived pressure and fraud occurrences (Holtfreter et al., 2010; Mohamed et al., 2010). Mohamed et al. (2010) reviewed the role of the market regulators in Malaysia, particularly the Malaysian Securities Commission. They also analysed the fraud cases published on the Malaysia Securities Commission's website. Their findings indicated that racial-distribution analysis of fraud perpetrators consists of the Chinese with a high record of 115 fraud cases against the total of 176 perpetrators. One possible reason to such high number could be due to the fact that the numbers of Chinese people in the business line are higher than the Malays and Indians.

Hasnan et al. (2013) examined the factors influencing fraudulent financial reporting in the emerging market of Malaysia. Their study found that financial distress variable has significant positive relationship with fraudulent financial reporting. They indicated that a company under financial distress would likely do fraudulently financial reporting in order to show more favourable results such as overstating asset or revenue, or understating liability. Hollow (2014) conducted his study on bank employees and managers to determine the factors influencing bank managers and bank employees to commit fraudulent offences at workplace. His study revealed that financial pressure plays a huge significant role in motivating both bank employees and bank managers to commit fraud. However, the nature and level of financial pressure differs depending on the position held by the perpetrators.

Holtfreter et al. (2010); Bozorgian \& Kanani (2017) examined whether level of self-control (Note 2) influences the engagement of two common forms of fraudulent behaviour. The two common forms of fraudulent behaviour are cheque-fraud and credit card-fraud. Their study revealed that individuals with low level of self-control are more likely to commit cheque or credit card frauds. Hence, the way a person is brought up may also influence the possibility of him committing fraud.

\subsection{Perceived Opportunity}

The second element which is opportunity is the most vital element to fraud occurrences. A person may have the desire (pressure) to commit fraud but would not be able to it without the presence of opportunity (Fisher, 2015; Cressey, 1953; Mohamed et al., 2010; Voon, et.al., 2008). An opportunity arises in the absence of weak internal control. Weak internal control allows exploitation which led to opportunity for employees to commit fraud since they are less likely to get caught (Mohamed et al., 2010; Hasnan et al., 2013). Cressey (1953) suggested two basic aspects of opportunity namely, general information and technical skill. General information relates to an employee having the knowledge that allows him to take advantage of his position. That is, a person's ability to either violate a trust, or take advantage on a company based on his position. Technical skill on the other hand, refers to the skills needed to perpetrate the fraud. Hence, a combination of general knowledge and technical skill would put an organisation at stake if the employees have high desire to commit fraud (Fisher, 2015).

In terms of opportunity, studies have shown that there is a link between internal control adequacy and opportunities (Mohamed et al., 2010; Kennedy, 2012; Brown \& Ibekwe 2018). For example: Mohamed et al. (2010) examined the relationship between internal control procedures in terms of practices and policies towards fraud occurrences. Their studies indicated that internal control procedures in terms of practices have no significant relationship with fraud occurrences. Hence, their findings indicated that there is a negative relationship between good governance and fraud occurrences.

Fraud prevention is less costly for companies compared to fraud detection since it is unlikely for the companies to be able to recover the losses once the fraud has taken place. ACFE (2014) reported that less than $42 \%$ of the reported fraud cases could recover back their losses, whilst the remaining 58\% were recovered after a year of the fraud occurrence. Siregar and Tenoyo (2015) conducted their study to investigate the level of fraud awareness in the private sector in Indonesia. They also identified the steps that have been taken by companies to detect or prevent fraud. Their studies indicated that weak internal control and lack of ethical values are ranked as the most likely reasons for perpetrators to commit fraud. Rahman and Anwar (2014) examined the underlying determinants of fraud occurrences. They found first rank of factors influencing fraud consists of non-compliance followed by weak internal control and financial pressure in third rank.

Voon, et al. (2008) conducted their research to identify their respondents' view on factors influencing corporate crime activities in the public listed companies in Malaysia. They found that the reasons for fraud in an ordinal order are due to weak internal controls, personal financial pressure, maintain expensive or lavish lifestyle, greed, business financial pressure and gambling. Their study concluded that someone who is pressured with financial strain and associated with business or personal matters would be more likely to commit fraud. 


\subsection{Capability}

A body of the literature have examined the link between capacity and fraud occurrences (Zahra et al., 2005; Mackevicius and Griunas, 2013). For example: Wolfe and Hermanson (2004) argued that fraud may not take place if the employees do not have the capabilities to commit fraud. They stated that opportunity opens the doorway to fraud, while pressure and rationalization draws the person towards it. That is, only employees that have the capability would be able to detect existence of opportunity and proceed in taking the opportunity to commit fraud. Hence, the element of capability is imperative for fraud.

Wolfe and Hermanson (2014) believed that there are six essential traits in the personality of perpetrators. The six traits consist of position or function, brains, confidence or ego, coercion skills, effective lying and immunity to stress. Firstly, a person's position or function within an organization may furnish him with the ability to create or exploit opportunity to commit fraud. Secondly, employees that have the intelligence to understand and later exploit internal weaknesses and use their position, function or authorized access to their advantage (Mackevicius and Griunas, 2013). Thirdly, employees who possess strong ego and great confidence that their misconduct would not be detected; or the perpetrators think that they can get away even if they are being caught (Allan, 2003; Bugu \& Yucheng 2018). The next trait is ability to coerce others to commit or conceal fraud. The last trait is ability to manage stress. As committing and managing fraud from being detected is somewhat stressful, the fraud perpetrators must have the ability to conceal the fraud for a long time.

\section{Research Framework and Hypotheses}

Figure 1 depicts the research framework of this study. The research framework shows the relationship between the four elements of fraud and employees' intention to commit fraud. As shown in Figure 1, the dependent variable in this study is employees' intention to commit fraud. The two independent variables are perceived pressure and perceived opportunity.

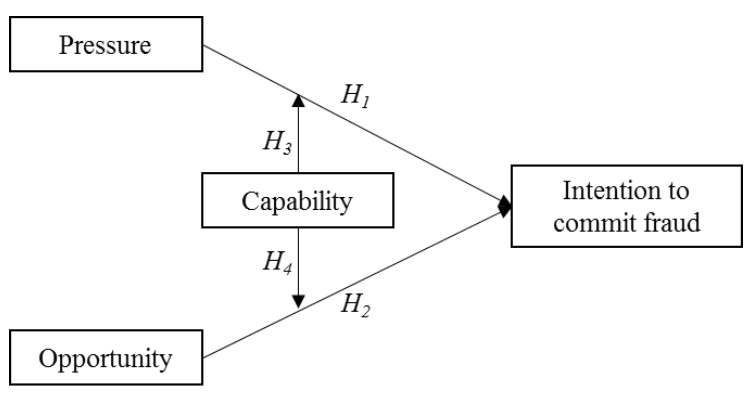

Figure 1. Research framework

Hasnan et al. (2013) indicated that financial distress positively and significantly influence fraudulent financial reporting. When a company is under financial distress, the company may fraudulently report more favourable results. Financial pressure plays a huge significant role in motivating both employees and managers to commit fraud. However, the nature of financial pressure depends on the role of the perpetrator (Hollow, 2014). According to Holtfreter et al. (2010), employees with low self-control are more likely to engage in cheque-fraud and credit card-fraud.

Employees who sit on the high-level position are also more likely to engage with fraudulent activities since they are more pressured. The degree of such pressure depends on their personal characteristics such as age, tenure and gender (Zahra et al., 2005). Arguably, perceived pressure can influence employees to commit fraud. Therefore, the following hypothesis is proposed:

$\mathbf{H}_{\mathbf{1}}$ Perceived pressure significantly influence employees' intention to commit fraud

Mohamed et al. (2010) in their study found a negative relationship between good governance and fraud occurrences. They found internal control procedure in terms of practices is not significant with fraud occurrences. However, according to Kennedy (2012), the more internal controls that a company designed and been implemented, the lesser the possibility of opportunities available for their employees to commit fraud. Kennedy's (2012) study was further supported by Voon, et al. (2008), Fisher (2015) and Siregar and Tenoyo (2015) who concluded that a person is likely to commit fraud due to weak internal controls. Studies on perceived opportunity indicated that perceived opportunity 
may or may not influence a person's intention to commit fraud. Thus, the following hypothesis is proposed:

$\mathbf{H}_{\mathbf{2}}$ Perceived opportunity significantly influence employees' intention to commit fraud

Wolfe and Hermanson (2004) indicated that fraud may not take place unless the right person who possess the right capabilities undertakes it. Finkelstein et al. (2009) and Zahra et al. (2005) stressed upon demographic characteristics that is associated with cognitive bases, values and perceptions that may influence the decision-making of managers. The demographic characteristics of tenure and length of service has been sought to be the most notable variables employed in strategic management and corporate governance studies. Employees with longer tenure at top-level or an organization are those who have greater knowledge, experience and are more mature (Finkelstein et al., 2009). Thus, the following hypothesis is proposed:

$\mathbf{H}_{3}$ The influence of perceived pressure on the intention to commit fraud is moderated by capability.

$\mathbf{H}_{4}$ The influence of perceived opportunity on the intention to commit fraud is moderated by capability.

\section{Research Design}

\subsection{Target Sample}

The target sample for this study is working adults who are currently employed. The reason for such selection is in line with the findings by KPMG (2004) which indicated that $87 \%$ of the perpetrators are employees within the organisation itself. Stevens (1996) recommended that 15 participants per predictor (independent variable) are required for a reliable for a social science research. Tabachnick and Fidell (2007) formulated the sample size requirements as the number of sample should be $\mathrm{N}>50+8 \mathrm{~m}$, where the $m$ refers to the independent variable. Hence, if based on Stevens (1996), there is a need to have a sample of at least 45 respondents, whereas if based on Tabachnick and Fidell (2007), the sample size would be at least 74 respondents with 3 independent variables. It is however important to note that such requirements are just the minimum requirement of the samples. In total, 220 respondents participated in this study. However, 62 of the respondents did not complete the questionnaire and therefore, are excluded in this study. The final sample is 158.

\subsection{Research Instrument}

The research instrument used in this study is questionnaire. The questionnaire is developed based on reviewing the literature related to occupational fraud. The questionnaire is divided into four parts namely, (i) perception on fraud; (ii) pressure; (iii) opportunity and (iv) demographic profile.

The first part requests the respondents to provide their perception on fraud. The purpose of this part is to measure the respondents' intention to commit fraud. However, the respondents are not inform on the purpose of this part apart from requesting them to provide their opinion whether to agree or not to agree with the questions posed in Part A. The questions in this part adopts Kaptien's (2012) instrument with some modification to suit the context of this study. Kaptien identified several traits that explains why good people sometimes do bad things at their workplace (refer Appendixes 2 and 3). There are 32 questions in this part such as 'what are the respondents' opinion on taking home office stationaries' and 'how do they view an unethical act'. This part uses a 7 point scale from ' 1 ' as strongly disagree to ' 7 ' as strongly agree.

The second part requests the respondents' perception on their level of pressure. The purpose of this section is to determine their level of pressure. There are 11 questions in this part. Among the questions asked are 'I do part time/ additional job to support my living', I have recently quarrelled with my partner due to financial problems' and 'my partner expects me to be financially stable for us to remain together'. This part uses a 7 point scale from ' 1 ' as strongly disagree to '7' as strongly agree.

The third part requests the respondents to provide their perception on opportunity within their working environment. There are 13 questions in this part including 'my company has proper set of internal control to deter fraudulent activities', 'my company fully enforces the internal control that has been set' and 'my company practices job-rotation after some time'. This part uses a 7 point scale from ' 1 ' as strongly disagree to ' 7 ' as strongly agree.

The final part of the questionnaire requests the respondents to provide their demographic profile such as age, working experience and education. These variables represent the moderating variable namely, capability. The questions in this part use a categorical scale to measure the response.

\subsection{Data Collection Procedure}

The data was collected through online survey over a period of two months. The questionnaire was distributed using online survey via Google Form and distributed via messages and social media platform. Due to this, this study could 
not determine the response rate. Acceptance and usage of online-surveys has been considered to simplify the survey process by providing a user-friendly, cost effective and time saving option (Smith, 2015). A covering note which is similar to the cover letter in the conventional questionnaire survey was provided at the beginning of the survey. The cover letter explains the objective of the study and provides assurance that all information provided is confidential

\section{Results}

\subsection{Employees' Intention to Commit Fraud}

Table 1 provides the details the descriptive statistics, factor loadings, reliability and validity test for all constructs forming up the dependent variable that represents the employees' intention on committing fraud. The result indicates a low mean score for all variables (2.90). This indicates that the respondents have low intention to commit fraud. The construct with the lowest mean score (1.68) is a free-rider problem. The free-rider problem is an issue where some people consider violating the rule to be acceptable because of the existence of another group of people who comply with the rule.

Most respondents disagreed that they have increased claims amount even though other employees have done it but were not being caught by their company. The highest mean score (4.81) is time pressure theory, where most of the respondents agreed that they will do whatever it takes to get their task completed. The skewness (0.536) score indicates a slightly positively skewed data with high scores on the lower end. This indicates that most respondents have low intention to commit fraud.

Table 1. Descriptive statistics and reliability test on intention to commit fraud

\begin{tabular}{|c|c|c|c|}
\hline List of Constructs and Measures & Mean & SD & $\begin{array}{l}\text { Factor } \\
\text { Loading }\end{array}$ \\
\hline \multicolumn{4}{|l|}{$\mathrm{KMO}=0.915$} \\
\hline \multicolumn{4}{|l|}{ Cronbach's Alpha $=0.924$} \\
\hline \multicolumn{4}{|l|}{ Skewness $=0.536$} \\
\hline \multicolumn{4}{|l|}{ Kurtosis $=-0.120$} \\
\hline 1. Tunnel vision & 3.20 & 1.773 & .500 \\
\hline 2. The reactance theory & 2.82 & 1.715 & .703 \\
\hline 3. Tunnel vision & 1.99 & 1.373 & .768 \\
\hline 4. $\quad$ Tunnel vision & 1.97 & 1.337 & .795 \\
\hline 5. The power of names & 2.74 & 1.561 & .593 \\
\hline 6. The power of names & 2.68 & 1.644 & .512 \\
\hline 7. Social bond theory & 3.01 & 1.663 & .597 \\
\hline 8. The Galatea effect & 2.96 & 1.606 & .508 \\
\hline 9. $\quad$ Time pressure & 4.81 & 1.378 & -.573 \\
\hline 10. Acceptance of small theft & 2.54 & 1.444 & .603 \\
\hline 11. Acceptance of small theft & 2.24 & 1.537 & .748 \\
\hline 12. Self-serving bias & 3.86 & 2.083 & .455 \\
\hline 13. Self-serving bias & 4.13 & 1.882 & .471 \\
\hline 14. Conspicuous consumption & 3.92 & 1.730 & .528 \\
\hline 15. The Pygmalion effects & 2.84 & 1.537 & .738 \\
\hline 16. Reactance theory & 4.27 & 1.853 & .413 \\
\hline 17. Obedience to authority & 2.68 & 1.503 & .663 \\
\hline 18. The blinding effect of powers & 3.66 & 1.458 & .369 \\
\hline 19. The broken window theory & 2.63 & 1.621 & .741 \\
\hline
\end{tabular}




\begin{tabular}{lllll}
\hline 20. & The free-rider problem & 1.93 & 1.307 & .721 \\
\hline 21. & The free-rider problem & 1.68 & 1.118 & .800 \\
\hline 22. & The foot on the door & 2.34 & 1.349 & .706 \\
\hline 23. & Winner take-all competition & 2.29 & 1.351 & .821 \\
\hline 24. & Cognitive dissonance and rationalization & 2.75 & 1.647 & .715 \\
\hline 25. & Problematic punishments & 3.71 & 1.991 & .487 \\
\hline 26. & Escalating commitment & 2.02 & 1.371 & .792 \\
\hline 27. & Market and shareholder pressure & 3.24 & 1.629 & .589 \\
\hline 28. & Market and shareholder pressure & 3.32 & 1.616 & .577 \\
\hline 29. & The compensation effect & 2.08 & 1.316 & .800 \\
\hline $30 . \quad$ Negative consequences of transparency & 2.76 & 1.775 & .677 \\
\hline 31. & Bad communication & 3.33 & 1.566 & .596 \\
\hline 32. & The pressure to confirm & 2.54 & 1.542 & .752 \\
\hline TOTAL & 2.90 & & \\
\hline
\end{tabular}

\subsection{Perceived Pressure}

Table 2 presents the descriptive statistics, factor loadings, reliability and validity test for all constructs to represent one of the independent variables namely, perceived pressure. The result indicates a low mean score of 3.20 for all variables. This indicates that the respondents perceived that they have low pressure. The construct with the lowest mean score of 2.30 is relating to the respondents' parent's relationship. Most respondents disagreed that their parents are in an unstable relationship. The highest mean score of 4.46 is relating to the usage of the respondents' salary, where most of the respondents agreed that a big portion of their salary is used for loan repayment. The skewness value of 0.223 and kurtosis value of 0.196 indicates a slightly positively skewed data with high scores at the lower end, which explains that a large number of the respondents have low pressure.

Table 2. Results of descriptive statistics and reliability on perceived pressure

\begin{tabular}{|c|c|c|c|}
\hline List of Constructs and Measures & Mean & SD & $\begin{array}{l}\text { Factor } \\
\text { Loading }\end{array}$ \\
\hline \multicolumn{4}{|l|}{ KMO = .644 } \\
\hline \multicolumn{4}{|l|}{ Cronbach's Alpha $=.701$} \\
\hline \multicolumn{4}{|l|}{ Skewness $=.223$} \\
\hline \multicolumn{4}{|l|}{ Kurtosis $=.196$} \\
\hline 1. Work -salary commensurate with job & 3.41 & 1.437 & .787 \\
\hline 2. Work - salary at par with market & 3.65 & 1.476 & .795 \\
\hline 3. Financial - salary used to repay loans & 4.46 & 1.695 & .557 \\
\hline 4. Financial - have savings for emergency & 3.00 & 1.523 & .594 \\
\hline 5. Financial - obtain loans to finance living & 2.96 & 1.845 & .622 \\
\hline 6. Financial-work part time & 3.22 & 1.881 & .450 \\
\hline 7. Others - relationship with partner & 2.58 & 1.717 & .803 \\
\hline 8. Others - partner's expectation & 3.12 & 1.963 & .581 \\
\hline 9. $\quad$ Others - parent's current relationship & 2.30 & 1.559 & .558 \\
\hline 10. Others - parenting practice & 3.99 & 1.829 & .650 \\
\hline TOTAL & 3.27 & & \\
\hline
\end{tabular}




\subsection{Perceived Opportunity}

Table 3 presents the descriptive statistics, factor loadings, reliability and validity test for all constructs forming up one of the independent variables, perceived opportunity. The result indicates a low mean score for all variables (3.20), an indication that the respondents have low perceived opportunity.

Table 3. Results of descriptive statistics and reliability on perceived opportunity

\begin{tabular}{|c|c|c|c|}
\hline List of Constructs and Measures & Mean & SD & $\begin{array}{l}\text { Factor } \\
\text { Loading }\end{array}$ \\
\hline \multicolumn{4}{|l|}{$\mathrm{KMO}=.785$} \\
\hline \multicolumn{4}{|l|}{ Cronbach's Alpha $=.770$} \\
\hline \multicolumn{4}{|l|}{ Skewness $=-.075$} \\
\hline \multicolumn{4}{|l|}{ Kurtosis $=-.372$} \\
\hline 1. Controls - company has internal controls & 2.63 & 1.412 & .675 \\
\hline 2. Controls - enforcement of internal controls & 2.85 & 1.468 & .779 \\
\hline 3. Controls - job rotation & 3.50 & 1.703 & .564 \\
\hline 4. Controls - checker-maker function & 2.72 & 1.387 & .655 \\
\hline 5. Controls - compulsory leave & 3.90 & 2.154 & .436 \\
\hline 6. Tone at the top-zero tolerance & 2.68 & 1.498 & .721 \\
\hline 7. Tone at the top - takes action on fraud & 2.33 & 1.407 & .747 \\
\hline 8. Tone at the top - walks the talk & 3.12 & 1.473 & .607 \\
\hline 9. Superior - performance discussion & 3.33 & 1.439 & 679 \\
\hline 10. Superior - review work & 3.21 & 1.410 & 609 \\
\hline 11. Superior - conducts ad-hoc review & 3.56 & 1.486 & .580 \\
\hline 12. Others - opportunities exist & 4.07 & 1.820 & .535 \\
\hline 13. Others - exposed to opportunities & 3.71 & 2.136 & .513 \\
\hline TOTAL & 3.20 & & \\
\hline
\end{tabular}

The construct with the lowest mean score of 2.33 is related to the respondents' company's action when a fraud is being discovered. Most respondents disagreed that their company has taken action on the perpetrators. The highest mean score of 4.07 is the avenues available to commit fraud in their job. Most of the respondents agreed that there are opportunities if they want to commit fraud. The skewness value of -0.075 and kurtosis value of -0.372 indicates a slightly negatively skewed data with higher score at the upper end. This explains that a large number of the respondents have low opportunity to commit fraud.

\subsection{Capability}

Capability is the moderator in this study which is represented by the employees' tenure in their current company. The results are shown in Table 4. The table shows that $68.3 \%$ of the respondents have less than 10 years of employment with the current company, whilst the remaining $31.7 \%$ have been with the company for more than 10 years.

Table 4. Tenure in current company

\begin{tabular}{lll}
\hline Tenure Group & $\mathbf{N}$ & $\mathbf{\%}$ \\
\hline 10 years and below & 68.3 \\
\hline Above 10 years & 31.7 \\
\hline
\end{tabular}


As the respondents' tenure in their current company in this study is in the form of categorical data, the researcher has converted these data into continuous variable. Conversion has to be performed from categorical to continuous variable because regression analysis treats all independent variables in the analysis as numerical (Skrivanek, 2009). In doing so, a dummy variable or indicator variable was created to represent the different period of tenure as shown in Table 5.

Table 5. Dummy coding for respondents' tenure in the current company

\begin{tabular}{lll}
\hline Tenure Group & Dummy 1 & Dummy 2 \\
\hline 10 years and below & 1 & 0 \\
\hline Above 10 years & 0 & 1 \\
\hline
\end{tabular}

\subsection{Effect of Perceived Pressure and Perceived Opportunity on Employees' Intention to Commit Fraud}

Table 6 presents the results of multiple regressions conducted to test the relationship between perceived pressure and perceived opportunity and the respondents' intention to commit fraud. The overall model is significant $(p<0.001)$. The $\mathrm{R}^{2}$ value in Table 6 indicates that the variance in the respondents' intention to commit fraud is explained by the model of perceived pressure and perceived opportunity. In this case, the value is 0.358 or $35.8 \%$ of the respondents' intention to commit fraud is explained by both perceived pressure and perceived opportunity.

Table 6. Regression analysis results

\begin{tabular}{llll}
\hline \multirow{2}{*}{ Variables } & \multicolumn{3}{l}{ Intention to Commit Fraud } \\
\cline { 2 - 4 } & $\mathbf{B}$ & $\boldsymbol{t}$ & Sig. \\
\hline (Constant) & 15.914 & 0.579 & 0.563 \\
\hline Perceived Pressure & 1.406 & 5.683 & $0.000^{*}$ \\
\hline Perceived Opportunity & 0.595 & 2.927 & $0.004^{*}$ \\
\hline Respondents' Tenure & 1.379 & 0.076 & 0.939 \\
\hline Pressure*Tenure>10 years & 0.405 & 0.928 & 0.355 \\
\hline Opportunity*Tenure>10 years & -0.377 & -0.826 & 0.410 \\
\hline $\mathbf{R}^{\mathbf{2}}$ & .358 & & \\
\hline Adjusted $\mathbf{R}^{\mathbf{2}}$ & .337 & & \\
\hline
\end{tabular}

*Significant at $\mathrm{p}$-value $=0.01$

Based on Table 6, the results explain the influence of perceived pressure on the respondents' intention to commit fraud. $\mathrm{H}_{1}$ suggests that perceived pressure significantly influences the employees' intention to commit fraud. The results indicate that the beta value (1.406) for the regression test is strong and significant. At 0.05 level of significance, with the $d f$ of $156(\mathrm{~N}-2)$, the $t$-critical value is 1.984 whilst the $t$-statistics value is 5.683 . Since the $t$-statistics (5.683) is greater than the $t$-critical value (1.984), hence rejecting null hypothesis. This study concludes that there is a positive significant relationship between perceived pressure and the respondents' intention to commit fraud. The observed $p$-value $(p<.001)$ too indicates that it is within the region of rejection where when $p$-value is lower than 0.05 , then reject the null hypothesis. Hence, $\mathrm{H}_{1}$ is supported. This study indicates that there is a positive significant linear relationship whereby the respondents' intention to commit fraud is influenced by the respondents' perceived pressure.

Table 6 also present the results explaining the influences of perceived opportunity on the respondents' intention to commit fraud. $\mathrm{H}_{2}$ suggests that perceived opportunity significantly influences employees' intention to commit fraud. The results indicated that the beta value (.595) for the regression test is week but significant. At 0.05 level of significance, with the $d f$ of $156(\mathrm{~N}-2)$, the $t$-critical value is 1.984 , while the $t$-statistics value is 2.927 . In this instance, since the $t$-statistics (2.927) is greater than the $t$-critical value (1.984), hence the null hypothesis is rejected. This 
study concludes that there is a positive significant relationship between perceived opportunity and respondents' intention to commit fraud. The observed $p$-value $(p=.004)$ too indicates that it is within the region of rejection where when the observed $p$-value is lower than 0.05 , thus, rejecting the null hypothesis. Hence, $\mathrm{H}_{2}$ is supported. This study indicates that there is a positive significant linear relationship whereby the respondents' intention to commit fraud is influenced by the respondents' perceived opportunity.

\section{Conclusion}

The first objective of this study is to examine the employees' intention to commit fraud. An analysis of the 158 respondents' response indicates that the respondents have low intention in committing fraud. Albrecht et al, (2012) indicated that the greater the perceived opportunity or the more intense the pressure on a person, the less rationalization it takes to motivate a person to commit fraud. Likewise, the more dishonest a perpetrator is, the less opportunity or pressure it takes to motivate a person to commit fraud. The low intention to commit fraud may fall back to the fact that the results in Table 4.5 that indicates the mean scores for both perceived pressure and perceived opportunity as low. The low mean scores for both these variables indicate that the respondents have low pressure and low opportunities to commit fraud. Based on the Fraud Scale perspective (Albrecht et al, 1984), there would be low intention to commit fraud if there are low pressure and low opportunities to commit fraud.

The second objective of this study is to examine the influence of perceived pressure and opportunities on the employees' intention to commit fraud. The results show that the changes in the level of intention to commit fraud is influenced by the respondent's perceived pressure This finding is in line with the past research conducted by Mohamed Saidque et al. (2010), Hasnan et al., (2013), Hollow (2014), and Holtfreter et al., (2010), where they concluded that perceived pressure influences a person's intention to commit fraud. This study also shows that perceived opportunity also influence changes in the level of intention to commit fraud is influenced by the respondent's perceived opportunity. This is in line with Cressey (1953) that postulated that an opportunity arises in the absence of weak internal control. This study gauges the respondents' opinion on the controls that are available within their organisation, and also the anti-fraud culture being practiced.

This findings on the positive relationship between perceived opportunity and the intention to commit fraud is however contradictory with the findings in Mohamed et al, (2010). Mohamed et al. concluded that internal control procedure in terms of practices is not significant with fraud incident which indicated a negative relationship between good governance and fraud incidences. The contradictory result on internal control practices and fraud incidents may explains that there is a possibility that the management may override internal controls or collusion between employees or third parties.

The third objective of this study is to examine the moderating effect of capability on the influence of perceived pressure and opportunities on the employees' intention to commit fraud. Thus the third and fourth hypotheses are developed. The capability is analysed based on the two different levels of tenure which was dummy coded into 10 years and below, and above 10 years tenure in the current company, this study indicates that a person with tenure above 10 years in the company does not have a significant relationship towards employees' intention to commit fraud. This is in line with the report by the KPMG Malaysia (2009), KPMG US (2011), KPMG Singapore (2014) and also ACFE (2014), which indicated that employees with tenure above 10 years in the current company have lesser fraud cases being reported, compared to those with 10 years and below.

This study is not without limitations. Although this study contributes to the understanding on the influence of perceived pressure and perceived opportunity towards an employees' intention to commit fraud, there are also some limitations that need to be highlighted. Firstly, the sample in this research may not generalize to the total population of the employees in Malaysia. The numbers of respondents and the ones accepted are comparatively low. Due to the sample size, any generalization of the research's results must be made with considerable caution.

Secondly, the industry or the field of the respondents is broad. As there are differences on level of pressure in the different level of position held by employees, the same would apply in terms of the industry that the respondents are working in. It is advised that future research is confined to a specific industry, or the research is conducted to compare means of two or more industries.

\section{Aknowledgment}

We wish to express our gratitude to the Faculty of Accountancy and Institute of Research Management and Innovation of Universiti Teknologi MARA for their support and funding. 


\section{References}

Albrecht, W. S., Albrecht, C. O., Albrecht, C. C., \& Zimbelman, M. F. (2012). Forensic Accounting. South Western Cengage Learning, Fourth Edition. Canada.

Allan, R. (2003, May). The human face of fraud,. CA Magazine, 136(4), 39-41.

Association of Certified Fraud Examiners. (2010). Who is Most Likely to Commit Fraud at Your Company. Retrieved from http://www.acfe.com/press-release.aspx?id=16 77

Association of Certified Fraud Examiners. (2014). Report to the Nations on Occupational Fraud and Abuse.

Bahrin, F. K., Azman, A., Zainol, I. N. H., Yusof, M. M., \& Shaed, M. M. (2018). The Level of Knowledge of Secondary School Students in Penang About HIV/AIDS: Pre and Post Intervention. International Journal of Asian Social Science, 8(8), 540-548. https://doi.org/10.18488/journal.1.2018.88.540.548

Bazmi, N. A., \& Javed, N. (2018). Under-Utilization of Female Capital: A Quantitative Study in Pakistani Perspective. International Journal of Business, Economics and Management, 5(4), 104-116. https://doi.org/10.18488/journal.62.2018.54.104.116

Boehm, F. (2007). Regulatory capture revisited: Lessons from economic of corruption. Working Paper, Research Centre in Political Economy.

Bosupeng, M. (2018). Leading Indicators and Financial Crisis: A Multi-Sectoral Approach Using Signal Extraction. Journal of Empirical Studies, 5(1), 20-44. https://doi.org/10.18488/journal.66.2018.51.20.44

Bozorgian, H., \& Kanani, S. M. (2017). Task Repetition on Accuracy and Fluency: EFL Learners'Speaking Skill. International Journal of English Language and Literature Studies, 6(2), 42-53. https://doi.org/10.18488/journal.23.2017.62.42.53

Brown, E. D., \& Ibekwe, E. E. (2018). Effect of Institutional Factors on Foreign Direct Investment in Nigeria. The Economics and Finance Letters, 5(1), 12-27. https://doi.org/10.18488/journal.29.2018.51.12.27

Bugu, Z. Y., \& Yucheng, H. (2018). An Empirical Analysis of the Factors Affecting the Profitability of China's Agricultural Listed Companies under the Background of Agricultural Modernization. International Journal of Applied Economics, Finance and Accounting, 2(1), 19-26. https://doi.org/10.33094/8.2017.2018.21.19.26

CIFAS. (2007). Growth in Staff Fraud Prompts New Guidance from CIPD and CIFAS to Help Businesses. Retrieved from

https://www.cifas.org.uk/secure/contentPORT/uploads/documents/Press\%20Release/Pre\%202008/Growth\%20i n\%20staff $\% 20$ fraud\%20prompts\%20new\%20guidance $\% 20$ from\%20CIPD $\% 20$ and $\% 20$ Cifas $\% 20$ to $\% 20$ help $\% 2$ Obusinesses.pdf

CIMA. (2009). Fraud Risk Management: A Guide to Good Practice.

Cressey, D. R. (1953). Other people's money; a study of the social psychology of embezzlement (p. 191). New York, NY, US: Free Press.

Edelhertz, H. (1970). The Nature, Impact, and Prosecution of White Collar Crime. US Government Printing Office, Washington, DC.

Finkelstein, S., Hambrick, D., \& Canella Jr. (2009). A strategic leadership: Theory and research on executives, top management teams, and boards. New York Oxford University Press, Inc. https://doi.org/10.1093/acprof:oso/9780195162073.003.0005

Fisher, K. (2015). The Psychology of Fraud: What Motivates to Commit Crime?. Texas Woman's University, Graduate School of Management. https://doi.org/10.2139/ssrn.2596825

Free, C. (2015). Looking Through the Fraud Triangle, A Review and Call for New Directions. Meditari Accountancy Research, 23(2), 175-196. https://doi.org/10.1108/MEDAR-02-2015-0009

Hasnan, S., Abdul Rahman, R., \& Mahenthiran, S. (2013). Management Motive, Weak Governance, Earnings Management, and Fraudulent Financial Reporting: Malaysian Evidence. Journal of International Accounting Research, 12(1), 1-27. https://doi.org/10.2308/jiar-50353

Herbert, C. F. (2005). Public sector experiences and challenges. National Congress on Integrity.

Hollow, M. (2014). Money, morals and motives: An exploratory study into why bank managers and employees commit fraud at work. Journal of Financial Crime, 21(2), 174-190. https://doi.org/10.1108/JFC-02-2013-0010 
Holtfreter, K., Beaver, K. M., Reisig, M. D., \& Pratt, T. C. (2010). Low self-control and fraud offending. Journal of Financial Crime, 17(3), 295-307. https://doi.org/10.1108/13590791011056264

Kennedy, K. A. (2012). An analysis of fraud: Causes, prevention and notable cases. University of New Hampshire Scholars' Repository.

KPMG Forensic Malaysia. (2004). Fraud Survey 2004 Report.

KPMG Forensic Malaysia. (2013). KPMG Malaysia Fraud, Bribery and Corruption Survey 2013.

Mackevicius, J., \& Giriunas, L. (2013). Transformational Research of the Fraud Triangle. EKONOMICA, 92(4), 150-163. https://doi.org/10.15388/Ekon.2013.0.2336

Mohamed, M. (2013). Countering Fraud in the Insurance Industry: A Case Study of Malaysia. University of Portsmouth.

Mohamed, N., Mohd Sanusi, Z., Marjuni, N. S., \& Johari, R. J. (2010). The Effectiveness of Internal Control System Towards Deterring Fraud In Government Agencies. Accounting Research Institute \& Faculty of Accountancy UiTM.

Murphy, P. R., \& Dacin, M. T. (2011). Psychological pathways to fraud: Understanding and Preventing Fraud in Organisations. Journal of Business Ethics, 101(4), 601-618. https://doi.org/10.1007/s10551-011-0741-0

Rahman, R. A., \& Anwar, I. S. K. (2014). Types of Fraud among Islamic Banks in Malaysia. International Journal of Trade, Economics and Finance, 5(2), 176-179. https://doi.org/10.7763/IJTEF.2014.V5.365

Rowlingson, K., Whyley, C., Newburn, T., \& Bertoud, R. (1997). Social Security Fraud: The Role of Penalties. Social Security Research Report Number 64. London: HMSO.

Sainsbury, R. (2003). Understanding social security fraud. In: J. Millar (Ed.), Understanding Social Security: Issues for Policy and Practice (pp. 277-295). Bristol, UK: The Policy Press.

Shanmugam, J. K., Che Haat, M. H., \& Ali, A. (2012). An exploratory study on internal control and fraud prevention measures in SMEs. International Journal of Business Research and Management (IJBRM), 3(2), 90.

Siregar, S., \& Tenoyo, B. (2015). Fraud awareness survey of private sector in Indonesia. Journal of Financial Crime, 22(3), 329-346. https://doi.org/10.1108/JFC-03-2014-0016

Tabachnick, B. G., \& Fidell, L. S. (2007). Using multivariate statistics (5th ed.). Boston: Pearson Education.

The Malaysian Insider. (2013). Hundreds of millions swindled from banks in past 5 years, mostly by staff, say police. Retrieved

from http://www.themalasianinsider.com/malaysia/article/hundreds-of-millions-swindled-from-banks-in-past-5-years mostly-by-staff-sa\#sthash.3oXAvBkv.dpuf

Voon, M. L., Voon, S. L., \& Puah, C. H. (2008). An empirical analysis of the determinants of corporate crime in Malaysia. International Applied Economics and Management Letters, 1(1), 13-17.

Wells, J. T. (2001). Why Employees Commit Fraud: Its either greed or need. Journal of Accountancy. Retrieved from http://www.journalofaccountancy.com/issues/2001/feb/whyemployeescommitfraud.html

Wolfe, D. T., \& Hermanson, D. R. (2004, December). The Fraud Diamond: Considering the Four Elements of Fraud, Management Fraud. CPA Journal, 38-42. https://doi.org/10.1016/S1361-3723(04)00065-X

Zahra, S. A., Korri, J. S., \& Yu, J. (2005). Cognition and international entrepreneurship: Implications for research on international opportunity. International Business Review, 14, 129-146. https://doi.org/10.1016/j.ibusrev.2004.04.005

\section{Notes}

Note 1. Pressure can include almost anything including medical bills, expensive tastes and addiction problems among others. Most of the time, pressure comes from a significant financial need/problem. Often this problem is non-shareable in the eyes of the fraudster (Chima, 2016).

Note 2. Low self-control is primarily determined by parenting during early childhood. Specifically, ineffective and/or inconsistent parenting practices such as failure to recognise and/or or punish unruly behaviour) result in children who are unable to delay gratification, avoid risky behaviour, control their impulses, and consider the feelings of others (Gottfredson and Hirschi, 1990). 